\title{
The Quest for Today's Totemic Psychology: A New Look at Wundt, Freud and Other Scientists
}

\author{
Yueh-Ting Lee, ${ }^{1}$ Xiangyang Chen, ${ }^{2}$ Yongping Zhao, ${ }^{3}$ and Wenting Chen ${ }^{4, *}$ \\ ${ }^{1}$ Department of Psychology, Southern Illinois University Carbondale \\ 2 Department of Psychology, Hunan Normal University, China \\ ${ }^{3}$ Faculty of Psychology, Southwest University, China \\ ${ }^{4}$ College English Department, Capital Normal University, Beijing, China
}

\begin{abstract}
T otems are symbols or representations of human's affiliations with, and/or categorizations of, animals, plants and inanimate objects. Totemism is related to fundamental human belief systems based on totems. Investigating totems and totemism psychologically is a unique way to explore human minds. We have critically examined Wundt, Freud and many other scholars and scientists who made distinguished contributions to scientific research on totems and totemism almost in the past two centuries -i.e., totemic psychology, which is the study of our mind's categorization and affiliation in the human and natural world today. Understanding and appreciating their totemic psychology can help psychologists today enhance their understanding in other fields-e.g., ecological and environmental psychology, biological psychology, cognitive psychology, personality, social and ethnic psychology, clinical and counseling psychology, cultural psychology, and religious or spiritual psychology. Unfortunately, recent data from a content analysis via Psyclnfo and a cross-cultural survey study $(N=273)$ showed that well-trained psychologists around the world and psychology students in the United States and in China are unfamiliar with Wundt and Freud's totemic contributions to psychology today. The implications, benefits, and lessons of totems and today's totemic psychology are discussed here.
\end{abstract}

Keywords Totems, Totemic Psychology, Wundt, Freud

"Totemism has already taxed the wisdom and the ingenuity
of many scholars, and there are reasons to believe that it will
continue to do so for many years."
\[ \text { - van Gennep (cited from Levi-Strauss, 1962, p. 4). } \]

\section{Introduction: Connection with Totems}

This article aims to address what totems, totemism, and totemic psychology are and how they relate to our daily life. It also addresses the virtually forgotten but essential research Wilhelm Wundt and Sigmund Freud did on totems and totemic psychology and the reasons why psychologists today should study totems and totemic psychology.

Before we define totems or totemism, a question arises: What does a totem or totemic psychology have to do with us in our own life? Consider the following practical exam- ples. We share last names (or surnames) with others and have representatives or icons in academic fields or professional occupations. Most institutions in North America have their animal mascots. Monies (coins or paper currency) have certain meaningful pictures. A nation has a flag with which its citizens may identify. Many have religious or spiritual beliefs. All these are examples demonstrating how totems and totemic psychology explicitly and implicitly relate to our daily life today.

More specifically, as an example, our name, especially the last name (or surname) is the vestige of totems. In his Elemente der Völkerpsychologie, Wundt (1912, p. 116) held that the totem animal "is usually regarded as the ancestral animal of the group" and is also indicative of its ancestral name. Based on Wundt's and other research (Durkheim,

Address for correspondence: Yueh-Ting Lee, Ph.D., Department of Psychology, Southern Illinois University Carbondale, Carbondale IL62901, USA (email: Leey@siu.edu or liyueting@yahoo.com).

*We appreciate the following colleagues for their valuable comments and other help- Stanley Krippner, Jeanne Brockmyer, Stephanie Flower, Joni Mihura, Harry Triandis, Steven Pinker, Alan Fiske, Susan Fiske, Clark McCauley, Craig Palmer, Jon Elhai, Jason Rose, Jim Nemeth, Barbara Mann, Jessica Meissner, Eugeniette Lee, Eric Atkinson, Jennifer Lee, and Michelle Beddow, and several students in Dr Lee's research laboratory. We are also grateful to Rogene Kohler for helping to translate several pages of Wundt's original German writing into English. We are responsible for any weakness or limitation in the paper. 
1902; Frazer, 1910; Lang, 1905), Freud who synthesized all totem research at his time stated that, "'Totem' is, on the one hand, a group name, and, on the other, a name indicative of ancestry, " i.e., "nomenclature of tribal divisions" and "the idea of ancestry" (see Freud, 1913/1950, p. 106). Though some people in modern society, especially those from the individualistic societies, pay little attention to their names and see their names as something insignificant (see Lee \& Tiamiyu, 2010), people in ancient times or in many tribal groups in certain parts of the world today regard their names as something "significant and essential" (Freud, 1913/1950, p. 112). As Freud stated, "the origin of the name had been forgotten," and a person's name "is a principal component" of his or her "personality," and "perhaps even a portion" of his or her "soul" (p. 112).

Almost every organization or group has a visual identity or very important late figure, which is a vestige of totems. For example, the logos of many organizations (e.g., American Psychological Association) or nations could be visual representations of their totems. Our psychological icons or psychologically representative "ancestors" (e.g., Wundt, Freud and many others) are definitely our totems. Even though we do not worship them spiritually, we respect them academically and psychologically or as psychologists (see Lee, Beddow, Chan \& Xu, 2015; Lee \& Kanazawa, 2015; Lee, McCauley, \& Jussim, 2013).

Very visible and common are mascots used by their institutions or American sports teams (e.g., The Buckeyes at Ohio State University, Wolverines at University of Michigan, Eagles or Falcons used by several institutions). Those totems or logo-images contain the created, interpreted and shared meanings of those totems or logo-images among members of a group or tribe (in comparison with others who may not share it) as demonstrated by researchers in psychology, anthropology and sociology. ${ }^{1}$ Most people around the world are religious. According to Durkheim (1915/2008) and other research (Lee et al, 2015), major religions, including philosophical beliefs, (e.g., Jesus Christ, Mohammed, Buddha, God, Allah, Karma in India; Jain Dharma in ancient India, Tao or Dao in China) are related to shamanism which is based on totemism symbolically or spiritually. If some people are irreligious or atheistic, they are still organized in different social groups or categories, which is no different from those people in different tribal groups in China, in Americas, or other parts of the world where people still respect and honor animal or plant totems (He, 2006, 2007; Lee et al, 2015). For example, totems and totem poles are alive and very meaningful to the native people of Southeast Alaska (e.g., the Haida, the Tsimshian, the Tlinkit, see Curtis, 1972; King, 2008). Totems are omnipresent in our life. Simply put, totems are symbols or representations of human's affiliations with, and/or categorizations of, animals (or animal kingdom), plants and inanimate objects, and totemism is related to fundamental human belief systems based on totems.

\section{How did Wundt, Freud and Other Scientists Address Totems and Totemism Scientifically?}

Wundt (1916) and Freud (1950) defined totem as a group name and a representative connection with ancestry. Originally, the word totem is taken from the language of the Ojibwa, or as the English called them, the Chippewa Indians (Wundt, 1916):

\begin{abstract}
The 'totem' signified first of all a group. Persons belong to the same totem if they are fellow-members in a group which forms part of a tribe or of a clan. The term 'clan,' suggested by the clan divisions of the Scottish Highlanders, is the one usually employed by English ethnologists in referring to the smaller divisions of a tribe. The tribe consists of a number of clans, and each clan may include several totems. As a rule, the totem groups bear animal names. In North America, for example, there was an eagle totem, a wolf totem, a deer totem etc. In this case, animal names regularly refer to particular clans within a tribe; in other places, as, for example, in Australia, they designate separate groups within a clan. Moreover, the totem animal is also usually regarded as the ancestral animal of the group in question. 'Totem,' on the one hand, is a group name, and on the other, a name indicative of ancestry. (p. 116)
\end{abstract}

Both Wundt (1916) and Freud (1950) were aware of the origin of the word "totem." That is, it was first mentioned by John Long (1791/1922), an English man adopted into the Ojibwa tribe, and each Ojibwa Indian described a totem as a favorite spirit which the Ojibwa Indians believed watched over them (Long, 1791/1922, p. 110). This totem, American Indians believe, "assumes the shape of some beast or other, and therefore they never kill, hunt or eat the animal whose form they think this totem bears" (Long, 1791/1922, p. 110). Second, though McLennan $(1869,1870)$ described the worship of animals and plants, Morgan was the first American anthropologist who clearly stated that the term "totem" originated in the Ojibwa Indian language, pronounced "dodaim” (Morgan, $1877 / 1974$, p. 170) which strongly influenced Wundt and Freud. A tribal totem signifies the symbol or device of a gens, or clan, as observed in the fieldwork with Chippewa Indians in Michigan, Minnesota, North Dakota, South Dakota, and Alaska (Lee, 2010, 2012), and also confirmed in the works of Chinese archeologists and/or anthropologists (i.e., tao-tiem or Tsotsom-see Lin, 2001; Wang \& Song, 2007).

Scientifically, totem is a belief regarding certain things (e.g., animals, plants or objects) that are commonly and sacredly shared and worshipped by a group of people (family, clan, tribe). This definition is consistent with what scholars discussed in various fields such as psychology (e.g., Freud, 1913/1950; Rivers, 1909; Wundt, 1912, 1916; also see Lee, Jussim \& McCauley, 2013), anthropology (e.g., Bateson, 2002; Boas, 1916; Frazer, 1910; Goldenweiser, 1910; LeviStrauss, 1962; Morgan, 1877/1974; Palmer, Steadman, Cassidy \& Coe, 2008; Pedersen, 2001) and sociology and other sciences (Durkheim, 1902/1985; Jones, 2005; Lang, 1905; Spencer, 1870). With respect to totemism, a general 
review of literature by the scientists above shows three primary "features of the relations between human beings and the classes of animals, plants or inanimate objects which constitutes the essence of totemism" (Rivers, 1909, p. 156) as follows:

The first and most important feature is that the class of animals
or other objects are definitely connected with a social division,
and in the typical form of the institution this social division is
exogamous. Often the division takes its name from the totem,
or this maybe used as its badge or crest; but these points are less
constant and essential. The second feature is the presence of a
belief in kinship between the members of the social division
and the totem, and in the most typical form there is belief
in descent from the totem. The third feature is of a religious
nature; in true totemism the members of the social division
show respect to their totem, and by far the most usual method
of showing this respect is the prohibition of the totem as an
article of food. When these three features are present, we can
be confident that we have to do with totemism. (Rivers, 1909,
p. 156)

In other words, totems or totemism may have three major elements-i.e., social, psychological, and ritual element (also see Levi-Strauss, 1962, p. 8).

\section{The Types of Totems}

There are various types of totems-e.g., tribe/group, sex, and individual totems (Wundt, 1916). More specifically, Freud (1913/1950) addressed:

Totems are of at least three kinds: (1) the clan totem, common to a whole clan, and passing by inheritance from generation to generation; (2) the sex totem, common either to all the males or to all the females of a tribe, to the exclusion in either case of the other sex; (3) the individual totem, belonging to a single individual and not passing to his descendants. (p. 103)

First of all it is very clear that a clan or tribe totem signifies the symbol or device of a gens. According to Morgan (1877/1974), the figure of a wolf was the totem of the Wolf gens; in addition to the Wolf gens, there were also other gens, such as Bear, Beaver, Turtle, Snipe, Crane, Duck, Snake, Carp, Cat Fish, and Pike which were their totems (p. 107).

Also, "each sex can have an emblem, such as a bird or animal, which usually signifies solidarity of that sex as distinct from the other. Injuring or killing the sex totem animal is like challenging or attacking the sex associated with it. An example was observed among the Kurnai of Gippsland in Australia" (Monroe, n.d.; also see Durkheim, 1915/2008, pp 164-165). Among these people "the emblems of the sexes are two different birds, one for each sex, who regard them as elder brother for men and elder sister for women. In this society marriages take place by elopement, and the girls can refuse a suitor." (Monroe, n.d.; also see Durkheim, pp 164-165). Sex totems seem to be popular only among native Australians.

According to Frazer (1910) and Wundt (1916, pp. 178180), the last two (i.e., individual and sex totems) are less important than the tribal totems, and the tribal totem is reverenced by its members who call themselves by the name of the totem, and the tribal members believe themselves to be of one blood, descendants of a common ancestor. They are bound together by common obligations to each other and by a common faith in the totem. Totemism (i.e., a belief in totem) could be considered both a spiritual and social system. There are two important points here. First, totem is a name indicative of ancestry. A totem animal is usually regarded as an ancestral animal (see Durkheim, 1915/2008; Wundt, 1916). Second, totem is a group name, which could often be found among American Indians as discussed by Morgan (1877/1974).

\section{Theories of the Origin of Totems and Totemism by Wundt, Freud, and Other Scientists}

Why did human beings have totems in the first place? Where did totems originally come from? In the field of psychology, if Wundt is one of the pioneers who addressed totems and cultural or folk psychology independently, Freud is the psychologist who stood on the shoulders of many scientists and scholars of totemism in the 19th century and in the beginning of the $20^{\text {th }}$ century. By and large, based on Wundt, Freud and other scholars' research, four major types of theories are synthesized in order to explain the origin of totems and totemism as follows-i.e., biological and exogamous theories, nominalistic theories, sociological theories, and psychological theories.

Biological and Exogamous Theories. According to Wundt (1916), "totemic exogamy is characterized by the fact that a member of one specific clan, or of a totem group belonging to the clan, may enter into marriage only with a member of another clan or totem group," and this restriction of the marriage relationship is generally known as "exogamy" (pp. 144-145). In this regard, Freud (1913/1950) reviewed and analyzed various perspectives and findings of the exogamous theories by other scholars (e.g., Durkheim, 1902; Frazer, 1910, McLennan, 1869; Morgan, 1877). As a taboo, marriage or sexual behavior within a clan or family is biologically and psychologically detrimental. For example, biological inbreeding causes genetic deficiency, and psychological animosity or jealousy within the totem group. Consistent with Frazer (1910) and Lang (1905) on exogamy and totemism (also see Malinowski, 1927), Freud (1913/1950) held that biologically, "inbreeding is detrimental to the species" and "civilized men have come to the conclusion that the satisfaction of these natural instincts is detrimental to the general interests of society" (p. 123). Based on Darwin's research, exogamous theories would produce what grew into a conscious law: "No sexual relations between those who share a common home," and after the establishment of totemism, another regulation would run: "No sexual relations within the totem" (see Freud, 1913/1950, p. 126).

Nominalistic Theories. Basically nominalistic theories held that totems began because humans in various clans felt a need to distinguish themselves from one another 
by the use of names (Lang, 1905, p. 34; Wundt, 1916, pp. 187-188;). Totems were regarded as “'heraldic badges' by means of which individuals, families, and clans sought to distinguish themselves from one another" (also see Freud, p.110). Thus, a totem is a clan mark, then a clan name, then the name of the ancestor of a clan, and lastly the name of something worshipped by a clan (p. 110). From this, we can see that totemism did not arise from the religious need of humans but from their practical, everyday needs - nomenclature - and may be the result of the primitive writing technique. A totem is like an easily drawn pictograph.

However, once primitive people bore the name of an animal, they went on to form the idea of the kinship with it. This is consistent with the work of H. Spencer (1870) who regarded the giving of names as the decisive factor in the origin of totemism:

Very simply, savages habitually distinguish individuals by names that are either directly suggestive of some personal trait or fact of personal history, or else express an observed community of character with some well-known object. Such a genesis of individual names before surnames have arisen, is inevitable... If "the Wolf," proving famous in fight, becomes a terror to neighboring tribes, and a dominant man in his own, his son, proud of their parentage, will not let fall the fact that they descended from the Wolf; nor will this fact be forgotten by the rest of the tribe who held the "Wolf" in awe, and see some reason to dread his sons. In proportion to the power and celebrity of the Wolf will this pride and this fear conspire to maintain among his grandchildren and great grandchildren, as well as among those over whom they dominate, the remembrance of the fact that their ancestor was the Wolf. And ...this dominant family becomes the root of the new tribe, the members of this tribe will become known to themselves and others as the Wolves. (Spencer, 1870, pp. 538-539)

Freud (1950, p. 112), Wundt (1916, p. 187), and Lang (p. 1905, p. 125) basically agreed with Spencer in two aspects. First, an individual "name is a principal component of his personality, perhaps even a portion of his [or her] soul" (Freud, 1950, 112). Second, totems were created due to practical necessity just as individuals' security or identification numbers are often used.

Sociological Theories. Based primarily on the work by Frazer (1910), Wundt (1912), and Durkheim (1915), Freud (1913/1950) held that as an outcome of social organization, the totem is "the visible representative of social religion among the races concerned;" and it "embodies the community, which is the true object of their worship" (p. 113). A typical and well-discussed case is the Arunta tribe in Australia where those people worshipped their totems (i.e., plants). Further, they "believe that there are places scattered over the country [totem centers] at each of which the spirits of the dead of some totems await reincarnation and enter the body of any woman who passes by the spot" (Freud, 1913/1950, p. 114). These totem centers or spots are where people of the clan perform their collective ceremonies socially and culturally.
More explicitly, according to sociologist Durkheim (1915/2008), religious force is nothing other than the collective and anonymous force of the clan, and this can be represented in the mind only in the form of the totem. Thus, "the totemic emblem is like the visible body of the god" (Durkheim, 1915/2008, p. 221). In another sociological sense, a totem is like "the flag of the clan," and "the soldier who dies for his flag dies for his country" (p. 220).

Psychological Theories. The general literature reviewed by Freud (1913/1950) included perspectives of the origin of totems by psychologists (e.g., Wundt, 1912; Rivers, 1909) and anthropologists (e.g., Boas, 1916; Frazer, 1910). According to Wundt (1912, p. 190; 1916, p. 192), the original totem is the animal, and the earliest animals are identical with soul animals, and soul animals (such as birds, snakes, lizards and mice) are appropriate receptacles of souls. Therefore, "Totemism is directly connected with the belief in souls-that is to say, with animism," and "it represents that branch of animism which exercised a longcontinuing influence on the tribal organization as well as on the beliefs of people" (Wundt, 1916, p. 193).

The totem represents a safe place of refuge in which the soul could be deposited and so escapes the dangers that threaten it. When primitive people believed that they had deposited their souls in their totems, they thought that they were invulnerable and well-protected (Malinowski, 1926). They usually avoided eating or killing their totems. In some situations, they believe that totems could harbor the souls of their ancestors (Frazer, 1910; Malinowski, 1926, 2927). Similarly, Boas (1916) observed North American Indians and found that the totem was originally the guardian spirit of an ancestor.

\section{Why is Wundt and Freud's Totemic Psychology Important to Psychologists Today?}

Exploring Wundt and Freud's totemic psychology (or totemic mind) is not merely of historical value. More importantly their totemic psychology can enrich various areas significantly in psychology today as elaborated as follows.

\section{Totemic Psychology and Biological and Ecological (or Environmental) Psychology}

First of all, research on Wundt and Freud's totemic psychology helps to understand ourselves as human beings ecologically (or environmentally), and biologically. Today, we human beings cannot be separated from the natural world. With regard to totems and totemism, Wundt put it:

Man does not have dominion over the animal, but the animal rules man. Its deeds and activities arouse wonder, fear, and adoration. The souls of the dead dwell within it; it thus becomes the ancestor of man. Its flesh is prohibited to the members of the group by its name, or conversely, on ceremonial occasions, the eating of the totem-animal may become a sanctifying cult activity. (1916, p. 8) 
Wundt and Freud's totemic psychology may help us to understand not just ancient people but also many tribal groups around the world with regard to their relations with animals, plants, and objects and their customs of marriage and families. In a sense their work can make a unique contribution to modern environmental and ecological psychology. As shown in Durkheim's work (1915/2008), rocks, trees, and mounds of certain native people which were seen as sacred with ancestral souls (pp. 278-279) were supposed to be well-honored and should not be destroyed. Ecologically, it is meaningful to us to protect the natural environment. Among the Native American Indians today, there is a tendency to reaffirm their spiritual connection with their totem animals in order to protect wildlife and the land as environmentalism (Isaacson, 2000). For example, the Nez Perce tribe of Idaho regards the Wolf as the totem animal, which represents strength of family. Through a youth environmental and spiritual program in Alaska, young members of the Aleut tribe have rediscovered their spiritual links with the seal (Isaacson, 2000).

Also, for biological and other concerns, totemic exogamy is very helpful when we study mating, dating, sexual behavior and marriage evolutionarily. Totemic psychology prevents members with the same totem from inbreeding, which is believed to be biologically and psychologically detrimental (see Freud, 1913/1950; Malinowski, 1926, 1927). Bergson "sees totemism as a means of exogamy, this itself being the effect of an instinct intended to prevent biologically harmful union between close relatives" (quoted from Levi-Strauss, 1963, p. 94).

\section{Totemic Psychology, Human Mind and Cognitive Psychology}

Studying Wundt and Freud's totemic psychology helps to further understand human minds cognitively. If totems are visual representations and categorizations of animals, plants, and objects, totemization may be an effective process to organize both the human and the natural world cognitively. The world could be chaos without categorization or classification, and human beings cannot function without totemic classifications explicitly and implicitly (Lee, Jussim, \& McCauley, 2013; Levi-Strauss, 1966; Wundt, 1916). Totems scientifically serve a mental function of categorization, grouping and classification, and they link the natural world and the human world, and help us to categorize animals, plants, objects, and humans (Batson, 2002: Wundt, 1912, 1916). As part of the totemic process, modern stereotypes serve the same categorizing function (Jussim, 2012; Lee, 2014; Lee, Jussim, \& McCauley, 1995, 2013).

Let us use mascots of sports teams as an example. Many sports teams in the United States or Canada use animals as their mascots, which serve the same functions as totems. Some of us might have heard of the Detroit Tigers. Tribes or clans of human beings in ancient times or even in modern times (e.g., among the Native Americans in North and South Americas and certain ethnic groups in southwest China) still perceive animals as sacred totems as much as Christians honor and worship God (Alexander 1916/2005; He, 2006, 2007; Morgan, 1877/1974; Wundt, 1912/1916). As a category, the Detroit Tigers can be a symbol to unite those who support this sports team. Thus, tigers are group representations of totems both in the past and today.

In discussing totems, Levi-Strauss noted that one of the primary tasks of human beings, including both scientists and ethnic tribes, is to classify or categorize things around us and to minimize disorder and chaos, "Scientists do tolerate uncertainty and frustration, because they must. The one thing that they do not and must not tolerate is disorder." (Levi-Strauss, 1966, p. 9). Human observations and systematic categorizations of relations and connections "can sometimes lead to scientifically valid results" (p. 10). The Blackfoot Indians were able to prognosticate the approach of spring by the state of the development of the foetus of bison which they took from the uterus of females killed in hunting. The Navaho Indians "regard themselves as great as classifiers" (p. 39). Any classification, including totemic classification or stereotypic categorization, is "superior to chaos and even a classification at the level of sensible properties is a step towards rational ordering" (p. 15). One of the primary functions of stereotypes is to categorize individuals of groups based on certain properties (Jussim, 2012; Lee, Jussim, \& McCauley, 1995, 2013).

Clearly it makes sense that those tribal groups use totems to classify or categorize animals, plants or objects in order to survive and thrive generations after generations for thousands of years. Thus both stereotypes and totems are the outcomes of human categorization (i.e., social representations, see Moscovici, 1973, 1984, 1988). Understanding Wundt and Freud's totemic psychology can help us to better understand the human mind-i.e., understanding human cognition and human categories, which is very meaningful for the field of cognitive psychology.

\section{Totemic Psychology and Personality, Social and Ethnic Psychology}

Investigating Wundt and Freud's totemic psychology definitely enriches personality, social and ethnic psychology and helps us to understand ourselves as human beings. Several aspects of totemic psychology can aid in understanding personality and social psychology. First, if each individual has his or her own totem (an animal, a vegetable, or an object), the personal identity or self may be understood in relation to her or his totem, though not cited in today's psychology (see Jussim \& Ashmore, 1997). Second, according to nomenclature or nominalistic theories described above, individuals' personality could also be understood from research on totems (also see Spencer, 1870). Third, each sex among those native people in Australia has sex totems, and there is no doubt that understanding sex totems could help to understand sex or gender identity (see Freud, 1913; Wundt, 1912, 1916). 
Further, group totems lead to a very interesting and important inquiry into group identity and group temperament. With regard to group temperament, Bartlett $(1920,1932)$ used the folklore stories and coined the term "preferred persistent tendencies" (1932, p. 257) to address the objective different temperament between groups who worshipped different animals as their sacred heroic totems:

\begin{abstract}
That every effective social group does possess temperament, or if these descriptive terms are disliked, its own organized cluster of preferred persistent tendencies, seems to me to be certain... Some of the most interesting products of the social group are decorative and realistic art forms, and folk stories ... For example, in the culture-hero tales of the N.W. region of the N. America, we can find interesting comparisons between those of the group of Indians in the northernmost part of the coast area, those of Vancouver Island and the delta of the Frazer River, and those of the S. W. interior of British Columbia. The same basic stories are told in each group, but the first take the Raven as hero and center upon greed or voraciousness; the second take Mink as hero and center upon sex; and the third take Coyote as hero and center upon vaingloriousness or boasting. (Bartlett, 1932, p. 257)
\end{abstract}

In psychology, American social psychology has a long tradition of focusing on self and individual cognitive process (Lee, 1994; Lee \& Jussim, 2010). However, re-visiting Wundt and Freud's totemic psychology will bring us a new and fresh look into the collective thinking and behavior in social and ethnic psychology. As Wundt (1916) pointed out, totems, languages, folk religions and customs or myths as part of folk psychology may be "an indispensable supplement to the psychology of individual consciousness" (p.3).

Wundt is not only the pioneer of scientific experimental psychology but also the pioneer of modern social and ethnic/folk psychology (also Wundt, 1897, 1902). His 10-volume Völkerpsychologie showed that we need to understand both physiological and socio-cultural/ethnic aspects of human beings (i.e., folk psychology, see Blumenthal, 1975; Haeberlin, 1916). Though Wundt intentionally avoided the term social to be different from sociology (Wundt, 1916), socio-cultural or ethnic psychology was very important to him, and he saw it as "an essential complement to his experimental psychology and this vision would ultimately lead him, in the early 1900s, to the writing of a 10-volume survey of ethnographic data about the language, myth, and customs of diverse human cultures" (Cahan \& White, 1992, p. 227).

More specifically, according to Wundt (1916), "folk psychology really becomes a psychology of mankind" (p.4), and "the 'folk' is the most important collective concept" and "embraces families, classes, clans, and groups" (p. 4). Further, "folk psychology must be based on the results of ethnology" which "is the science of the origin of peoples, of their characteristics, and of their distribution over the earth" (p. 5). Ostensibly, personality, social and ethnic psychologists can learn from Wundt with respect to his research methodology and content.

For example, social identity theory (Tajfel, 1981; Tajfei \& Turner, 1986; also see Brown, 2000, Hogg, 2006; Swann, Jetten, Gómez, Whitehouse, and Bastian, 2012) and social representation theory (Moscovici, 1973, 1984, 1988, 2000; also see Bauer \& Gaskell, 2008; Wagner \& Hayes, 2005;) are important topics in social psychology. In fact, they are implicitly related to totemic psychology via Durkheim's work on individual and collective representation (Durkheim, 1974), i.e., individual and group totems which are related to our personal and social identity. According to Lukes (1972), Durkheim who "greatly admired Wundt's work" (p. 90) was further influenced by Wundt's work after he worked with Wundt for one year in Germany. If totems are also collective beliefs or representations, "the totem is not merely a name; it is an emblem, veritable coat-of-arms whose analogies with the arms of heraldry have often been remarked" (Durkheim, 1915/2008, p. 113). More specifically, "the totem is in fact a design which corresponds to the heraldic emblems of civilized nations, and each person is authorized to bear it as a proof of the identity of the family to which it belongs" (p. 113). Among the native people in Australia, each family adopted an animal or vegetable as their crest or sign; the American Indians used to paint their totems on their shields before going to battle (p. 113-114).

Even today, among these people both in Alaska (e.g., the Haida, Tsimshian, the Tlinkit) and in different parts of China (-e.g., the Yi, the Hmong, the Li, the Dai, see He, 2006, 2007; Wang \& Song, 2007), totems are engraved upon the woodwork and upon the walls. Totems are still alive and well-honored among various cultures along the Pacific Ocean. For instance, totem poles serve as social and cultural identity. Field research (Lee, 2010, 2012) and archival data (Jonaitis \& Glass, 2010) show that totem poles are the most significant symbols of cultural identity of the native people of Southeast Alaska (e.g., the Haida, the Tsimshian, the Tlinkit), and the carvings represent visual testimony or are like the books which record the people's genealogy and ancient stories, and also memorialize important events or individuals. In summary, investigating Wundt and Freud's totemic psychology will enrich further research in personality, social and ethnic psychology today.

\section{Totemic Psychology and Counseling and Clinical Psychology}

Studying Wundt and Freud's work will also enrich counseling and clinical psychology or psychotherapy. Here are two examples. First, according to Wundt (1916, p. 84), the chief of a totemic tribe could be a Shaman who has the authority and skills of treating patients with sickness or diseases. Developed based on totemism, shamanism is widely practiced around the world (Krippner, 2002; Sue \& Sue, 2012; Vitebsky, 1995; Winkelman, 2004). Shamans are both medical doctors and counselors/clinicians. "Among 
the American Indians, these were 'medicine-men'; the peoples of northern Asia called them 'shamans'" (Wundt, 1916, p. 84), and the medicine-man or -woman is "the predecessor of the modern physician, and also in a certain sense, of the modern priest" (p. 84). The Shaman or medicine person is feared and also honored as a helper in need.

Second, as a founder of psychoanalysis, Freud (1913/1950) was very meticulous in connecting totem animals with clinical or psychiatric problems, such as animal phobia, Oedipal complex, neurosis; emotional ambivalence (pp. 126-132). For example, phobias of animals (i.e., phobia of horses, dogs, cats, fowls, and other domestic animals) are "as common in childhood as pavor nocturnus"; and "in analysis they almost invariably turn out to be a displacement on to the animals of the child's fear of one of his parents" (Freud, 1913/1950, p. 128).

Today, there are many ethnic groups in North and South America (King, 2008) and in many parts of Asia $(\mathrm{He}, 2006,2007)$ who are still attached to their traditional totemic culture. They see their totem animals as their relatives (Curtis, 1972; Isaacson, 2000). But when teenagers or young people of those ethnic tribal groups are caught between their traditional beliefs and modern life, it leads to a high rate of drug, alcohol abuse, depression and suicide. As Isaacson (2000) pointed out, "Many of the youngsters had drifted so far from the traditional culture that they were dimly aware of the spiritual connection felt by the elders for the seals" (p. 69). Other research showed that understanding totemic psychology and tribal traditional beliefs (e.g., Shamanic beliefs) may help clinicians, counselors and psychotherapists to be more competent in their professional practice as demonstrated by other research evidence (e.g., Jilek, 1982; Meng, 2005; Sue \& Sue, 2012; Tolman \& Reedy, 1998; Vitebsky, 1995).

\section{Totemic Psychology and Cultural and Religious/Spiritual Psychology}

Studying Wundt and Freud's work will definitely help us in religious/spiritual psychology across cultures. First, considering the relation between totemic psychology, and personality, social and ethnic psychology, totemic psychology will enrich today's cultural and cross-cultural psychology. Anthropologists and ethnologists (e.g., Boas, 1916, Frazer, 1910; Levi-Strauss, 1962; Malinowski, 1926; Morgan, 1877) reported plenty of their cultural and crosscultural field findings in the past 150 years. Both Wundt (1916) and Freud (1913/1950) made the best use of those findings at that time (e.g., comparison of totems among the natives in Americas, in Australia, Asia and other parts of the world). Second, totemic psychology in the eyes of Wundt and Freud dealt with clans and tribes which are ethnic or cultural communities. Even today, many tribes in China or the Native people in Alaska still worship certain totems or totem poles in their villages, on their reservations or other kinds of communities. Spiritually it is similar to Shamanism or Shamanic practice (Jilek, 1982; He, 2007; Lee, 2012; Meng, 2005; Vitebsky, 1995).

Also, much research (see Wundt, 1916, Freud 1913/1950; Durkheim, 1915/2008) has shown that modern primary religions (e.g., Shamanism, Buddhism, Taoism, Hinduism, Judaism, Christianity, Islamism, Catholic, and others) may be originated from (at least implicitly may be related to) totems and totemism. By definition, "a religion is a unified system of beliefs and practices relative to sacred things, that is to say things set apart and forbiddenbeliefs and practices which unite into one single moral community called a Church, all those who adhere to them" (Durkheim, 1915/2008, p. 47), and totemism, based on animism and naturism, is an elementary religion (p. 87). Similarly, in his outline of a psychological history of the development of mankind, Wundt $(1912,1916)$ put human general development in the following chronological order: the primitive age, the totemic age, the age of heroes and gods, and the development of humanities (pp. xvii-xxiii), though probably controversial and debatable today.

A cautionary note is in order. A totem is not equal to a god. The difference between a totem and a god is that the former is concrete and vivid in our mind (e.g., animals, plants or inanimate objects) whereas the latter is abstract and developed from the former (Durkheim, 1915/2008; Wundt, 1912, 1916):

So we must be careful not to consider totemism a sort of animal worship. The attitude of a man towards the animals or plants whose name he bears is not at all that of a believer towards his god, for he belongs to the sacred world himself. Their relations are rather those of two beings who are on the same level and of equal value. The most that can be said is that in certain cases, at least, the animal seems to occupy a slightly more elevated place in the hierarchy of sacred things. It is because of this that it is sometimes called the father or the grandfather of the men of the clan... The totemic animal is called the friend or the elder brother of its human fellows. Finally the bonds which exist between them and it are much more like those which unite the members of a single family... On account of this kinship, men regard the animals of the totemic species as kindly associates upon whose aid they think they can rely. (Durkheim, 1915/2008, p. 139)

Another aspect of totemism is related to the native peoples' belief systems. For example, in Wundt's book in his original German language:

\footnotetext{
With the Indian tribes of North America, a lot of fairy tales have been preserved in connection with the deeply-rooted appearance of totemism, the cult of animal ancestors and guardian spirits, to which this oldest mythological character has remained. It is partly cosmogonic [theory of origin of the world] fairy tales, in which animals, namely birds, appear as bearers of great natural phenomena; partly it is tribe fairy tales, stories which report about the first origin and the animal ancestors of the tribe. (Wundt, 1905, p. 344) ${ }^{2}$
}

In other words, studying Wundt and Freud's totemic psychology will help us to better understand human religiosity and spiritual beliefs across cultures. In brief, it is clear that Wundt and Freud examined totems from 
a sociocultural or collective (not individual) perspective, which is a unique contribution to modern psychology, Further both addressed totems from various academic disciplines (beyond psychology). But Wundt influenced Freud (1913) who cited Wundt (1912).

\section{Need to Explore Wundt and Freud Fully Today-A Brief Report of Recent Quantitative Research on our Failure of their Totemic Contributions}

Almost every psychology student knows such names as Wilhelm Wundt and Sigmund Freud. Though they may not take any psychology courses, many non-psychology people around the world have heard about Sigmund Freud. Over twenty years ago, historians ranked Wilhelm Wundt, William James and Sigmund Freud as the most influential psychologists in the field whereas chairpersons of Psychology Departments also provided rankings of the importance and eminence of all time psychologists as follows: B. F. Skinner, S. Freud, W. James, J. Piaget, S. Hall and Wundt and Carl Rogers (Korn, Davis, \& Davis, 1991, p. 790).

In the textbooks of mainstream psychology, including the history of psychology, general psychology, experimental psychology, social and personality psychology, Wundt was recognized as the founder of scientific psychology who established the first psychology laboratory in Leipzig in 1879 (Boring, 1957; Goodwin, 2008) and Freud was seen as the founder of psychoanalysis (Boring, 1957; Leahey, 2004; Pickren \& Rutherford, 2010). While this is true, nothing was mentioned about their significant contribution to intensive investigation of totems, totemic psychology or about the influence of totems and human cultures on human behavior, cognition and mental health.

\section{APA Database}

In examining the American Psychological Association (APA)'s literature database of the American Psychologist (up to January 29, 2018 via PsycInfo), a total of 377 articles or writings were found to be related to Wilhelm Wundt and a total of 12,443 publications were found to be related to Sigmund Freud. Very few articles were found about totems with two exceptions, to our best knowledge. One is about Freud's book on totem and taboo that were well cited $(\mathrm{N}=110)$. Another exception is the article by Ausubel (1956) as follows: "Some of the psychiatrist's attitudes toward the psychologist stem from the fact that he himself is low man on the medical totem pole" (p. 102). This tells us nothing about what totem is and why certain ethnic and cultural groups respect and honor totems or totem poles.

Psychologists usually know the important writings or books such as Wundt's (1902) Principles of Physiological Psychology, Freud's (1913) Interpretation of Dreams or other writings (see Fancher, 2000; Wurtz, 1961). On the other hand, little attention has been paid to Wundt's
Elements of Folk Psychology (1912/1916) and Freud's Totem and Taboo (1913/1950). In the APA database of American Psychologist, no citation is related to Freud's Totem and Taboo (1913/1950), and based on the APA literature database of American Psychologist, there were very few articles which referred to Wundt's book (e.g., Anderson, 1971; Blumenthal, 1975; Cahan \& White, 1992). Taken together, psychologists are probably not quite familiar with Wundt or Freud's totemic psychology in the past 110 years.

If well-trained psychologists have not referred to Wundt and Freud's totemic psychology or totemic mind frequently, how about psychology students as a younger generation in the USA and in China? Did they know it better? A cross-cultural survey was performed with the objective to verify the degree to which we might have understood and appreciated Wundt and Freud's research completely. More specifically, we assessed how much American and Chinese college students today really understood or appreciated Wundt and Freud's totemic research.

\section{A Cross-Cultural Survey Study: Assessing College Students' Knowledge about Wundt and Freud's Totemic Contributions}

American and Chinese Participants. A total of 273 students who took psychology courses participated in this cross-cultural survey study to assess their knowledge about Wundt and Freud's totemic psychology. These psychology students included those undergraduate students who were primarily psychology majors and other students (who were taking psychology courses) from a university in Central China ( $\mathrm{N}=111)$ and from a university in the Midwest in the United States $(\mathrm{N}=162){ }^{3}$ There were 94 male college students and 179 female college students. Their mean age was 20.66 .

Survey Questions for Totemic Knowledge Assessment. To assess their knowledge about Wundt and Freud's totemic psychology, the following questions were asked: "What do you know about Sigmund Freud? Please list as much knowledge of him as you can below." Their responses were measured based on the number of accurate or relevant words counted for this question. Then, participants were further asked, "Based on your listed info above, to what extent do you think you understand the work of Sigmund Freud?" on a scale from 1 (not at all) to 7 (a great deal). These two questions were put together in order to increase the accuracy or validity of their knowledge measures (i.e., the more relevant information a participant could write, the more likely it was for him or her to report that she or he really knew something). Similarly, they were asked with regard to Wundt: "What do you know about Wilhelm Wundt? Please list as much knowledge of him as you can below." "Based on your listed info above, to what extent do you think you understand the work of Wilhelm Wundt?" on a scale from 1 (not at all) to 7 (a great deal). Third, they were asked about the knowledge of totems: "What do you know about totems? Please list as much knowledge of totems as you can below." "Based on your 
Table 1

General Response of Psychology Students about Knowledge of Wundt and Freud's Totemic Books

\begin{tabular}{lccccc}
\hline & \multicolumn{2}{c}{ Overall } & & \\
\cline { 2 - 3 } & Correct & Incorrect & & \\
\hline Match & & & & \\
Between Wundt and his book & $86(32 \%)$ & $183(68 \%)$ & & \\
Between Freud and his book & $55(21 \%)$ & $203(79 \%)$ & & \\
\hline & \multicolumn{2}{c}{ American Students } & & Chinese Students \\
\cline { 2 - 3 } \cline { 2 - 3 } & Correct & Incorrect & & Correct & Incorrect \\
\hline Match & & & & \\
Between Wundt and his book & $54(34 \%)$ & $104(66 \%)$ & & $32(29 \%)$ & $79(71 \%)$ \\
Between Freud and his book & $17(11 \%)$ & $141(89 \%)$ & $38(38 \%)$ & $62(62 \%)$ \\
\hline
\end{tabular}

Note. Correct choice or match between the book and the author=the correct choice of the book author for the question (Freud as the correct author of Totem and Taboo and Wundt as the correct author of Elements of Folk Psychology).

Table 2

American and Chinese Psychology Majors' Knowledge of Wundt and Freud's Totemic Psychology

\begin{tabular}{|c|c|c|c|c|c|}
\hline & \multicolumn{2}{|c|}{ American Psych Majors } & \multicolumn{2}{|c|}{ Chinese Psych Majors } & \multirow[b]{2}{*}{ F-Value } \\
\hline & Mean (SD) & $\mathrm{N}$ & Mean (SD) & $\mathrm{N}$ & \\
\hline 1. Words about Freud & $13.31(10.04)$ & 117 & $37.76(23.41)$ & 105 & $53.23^{* * *}$ \\
\hline 2. Really Know Freud & $3.53(1.71)$ & 113 & $3.81(1.12)$ & 103 & $17.79 * * *$ \\
\hline 3. Words about Wundt & $2.13(3.71)$ & 117 & $24.86(16.56)$ & 102 & $79.72^{* * *}$ \\
\hline 4. Really Know Wundt & $1.45(0.99)$ & 115 & $2.80(1.19)$ & 103 & $7.62^{* *}$ \\
\hline 5. Words about totems & $0.83(2.79)$ & 117 & $16.91(19.39)$ & 108 & $181.53^{* * *}$ \\
\hline 6. Really know totems & $1.11(0.70)$ & 116 & $2.57(1.36)$ & 80 & $69.25^{* *}$ \\
\hline 7. Correct choice of the book author for Freud & $1.08(0.36)$ & 116 & $1.39(0.50)$ & 98 & $71.73^{* * *}$ \\
\hline 8. Correct choice of the book author for Wundt & $1.29(0.51)$ & 116 & $1.30(0.50)$ & 108 & $0.87 \mathrm{~ns}$. \\
\hline
\end{tabular}

listed info above, to what extent do you think you really know about totems?" on a scale from 1 (not at all) to 7 (a great deal). Finally, two objective measures of knowledge were included with a multiple choice format: "Who is the author of the book entitled Elements of Folk Psychology? a. Karl Marx; b. Sigmund Freud; c. Lewis H. Morgan; d*. Wilhelm Wundt; and e. Charles Darwin"; and "Who is the author of the book entitled Totem and Taboo? a. Karl Marx; b*. Sigmund Freud; c. Lewis H. Morgan; d. Wilhelm Wundt; and e. Charles Darwin". The accurate answers are marked with *.

Basic Results and Short Discussion. As examined in Table 1, the results of the objective measures showed that over two-thirds of both American and Chinese psychology students could not accurately identify Wundt who wrote the book Elements of Folk Psychology or Freud who wrote the book Totem and Taboo. ${ }^{4}$

Specific inspection of Table 1 showed no statistical significance between the Chinese and American identification regarding Wundt, $\chi^{2}(1, \mathrm{~N}=203)=2.95, \mathrm{p}=. .23$, ns. On the other hand, a significant difference was obtained between Chinese and American psychology students in terms of their accurate identification regarding Freud, $\chi^{2}$ $(1, \mathrm{~N}=203)=29.1, \mathrm{p}=.001$.

Finally, cross-culturally, it appeared that Chinese psychology students knew Wundt and Freud's totemic psychology better than American psychology students (see Table 2) except Wundt's book which might be equally known. In other words, there was no significant difference between American and Chinese responses when they matched Wundt as author with his book Elements of Folk Psychology.

In summary, the understanding of both Wundt's and Freud's totemic psychology still has a long way to go. Both American and Chinese psychology students could have had greater or better knowledge about Wundt and about Freud. Chinese students might know it better than American students. In other words, American students knew less about totemic psychology than their Chinese counterparts.

\section{Conclusions and Implications: Benefits and Lessons for Totemic Psychology}

In his 532-page volume of Elements of Folk Psychology, Wundt (1916) devoted almost $1 / 2$ of its space to discussing 
totems, and Freud (1913/1950) produced a monograph of Totem and Taboo with over 172 pages. As discussed above, the former influenced the latter more rather than vice versa. According to Freud (1913/1950), totems have multiple functions: biological (e.g., members of the same clan or gens who were not supposed to have sexual relations), psychological and cultural (members of the same clan who shared the same identities, values, and beliefs, p. 116), religious (members of the same clan who believed in and worshiped certain animals or plants or objects), sociological (members in different tribes who were organized via totems instead of other categories), and clinical (certain members of a tribe who associated their illness with totem animals, see Lee, 2010).

If Wundt and Freud believed that studying totems was an effective approach to studying collective conscious and the unconscious mind, the evolutionary and anthropological research conducted by Spencer (1870) and Morgan (1877) produced a direct impact on Wundt and Freud. While recognized in the field of physiology, Wundt (1916) argued that it was not enough to study individual processes. The collective mental phenomena (i.e., the collective mind) should be equally significant, and human development and human behavior must be understood via "a synthetic survey" of folk psychology (Wundt, 1916, p. xiii). Historical and ethnological approaches to totems should be regarded as one of the methods to inquiry into folkways or folk psychology. As per Wundt (1916), our civilization was developed from the cultures of primitive people (e.g., their languages, marriage, family clans, totemic beliefs, thinking, art, heroes, tribal organizations, gods, rules and laws). Totems serve as a central transition in the process of this collective mind. Clinically and psychotherapeutically Freud (1913/1950) meticulously examined totems via his psychoanalytic approach to childhood and primitive emotion in great length, but he held a negative attitude toward tribal people, seeing them as neurotic savages. It is clear that taboos, which are based on totems within tribal groups, are the outcomes of collective mind rather than an individual mental process.

Wundt and Freud were the founders of the field of totemic psychology. What can we learn from Wundt and Freud from their research on totems? What conclusions can be reached here? First, totemic psychology is a study of people's beliefs in visual/symbolic or physical objects, as well as an approach to collective thinking-i.e., human minds for categorization and affiliation. This investigation may tell us that, as psychologists, perhaps we should advocate this field or approach, and Wundt and Freud's totemic psychology can definitely enrich various areas of psychology, such as biological psychology, environmental psychology, cognitive psychology, personality, social/ethnic psychology, cultural and cross-cultural psychology, counseling and clinical psychology, and religious and spiritual psychology.

Second, we psychologists must learn beyond the field of psychology. We need to be as multi-disciplinary or inter- disciplinary as possible. To study human thinking and mind, we may take into consideration human history, culture, evolution, philosophy, arts, social organization, and religious beliefs, just to name a few. It is clear that Wundt and Freud influenced and were also influenced by other scientists such as sociologists and anthropologists (e.g., Boas, 1916; Durkheim, 1915/2008; Frazer, 1910; Morgan, 1877; Spencer, 1870). If totems and totem poles are still very meaningful and sacred to diverse populations around the world today, Wundt and Freud's research on totems and totemic psychology provides us not only with much multi-disciplinary insight and scientific wisdom, but also with a unique way to understand and appreciate human diversity.

Third, Wundt built the first experimental lab in psychology and was regarded as a founder of scientific psychology, but it is important to remember that we must methodologically go outside our lab in order to study real social problems and cultural phenomena in the field-i.e. via fieldwork. Laboratory experimentation is one of the effective methods in psychology to deal with research issues. If we cannot learn from Wundt in a synthetic way, we psychologists cannot effectively solve social and psychological problems (Arnett, 2008; Lee, 1994; Lee \& Jussim 2010); nor can we justify our work on the human mind scientifically or clinically with regard to diverse cultures and life styles around the world (e.g., Lee, McCauley, Draguns, 1999; Lee, McCauley, Moghaddam, \& Worchel, 2004).

Fourth, American (and probably Western) psychology has been unfortunately dominated by individualism, individual mind or individual process (see Lee, 1994; Lee \& Tiamiyu, 2010; Triandis, 2009). Individualism, or individual mental process, is important but it is not enough. Like Wundt and Freud, we need to study the human mind in a collective and cultural-evolutionary way. This approach has been fortunately picked up by European psychologists and sociologists (e.g., Durkheim 1915/2008, 1974; Ichheiser, 1970; Moscovici, 1973, 1988, 2000; Tajfel, 1981) who have done research on social perception, social or group identity, and social representation.

Finally and most importantly, though unfortunately quantitative evidence has shown that both seasoned psychologists in the world and psychology students in the USA and in China today do not know much about Wundt and Freud's totemic psychology, it is necessary for our psychologists to learn the lessons due to their eminence of scientific research which still engages us today explicitly and implicitly. Wundt and Freud's totemic psychology is not only important historically but also contemporarily in various psychological fields. Totems are still alive and omnipresent everywhere. In short, it is never too late to pick up the legacy of Wundt and Freud's research on totemic psychology.

Goldenweiser (1914), a well-known psychological anthropologist wrote a review in Psychological Bulletin on Wundt's book Elements of Folk Psychology over 100 years 
ago, "The Elemente der Volkerpsychologie remains a contribution of consummate knowledge and wisdom, and its analysis of cultural processes stands, in its main conclusions, in close agreement with the findings of the modern Science of Man" (p. 391). Over half a century ago, Bruner (1956), a well-recognized cultural and cognitive development psychologist, who compared Darwin and Freud, made the following comments about the eminent work by Freud in American Psychologist.

Two figures stand out massively as the architects of our present-day conception of man: Darwin and Freud. Freud's was the more daring, the more revolutionary, and in a deep sense, the more poetic insight. (Bruner, 1956, p. 463-464)

To conclude, both Wundt and Freud cannot be forgotten, and particularly it is remiss of us as psychologists to ignore their eminent research on totemic psychology. Totems and totem poles are like books to teach us wisdom (Jonaitis \& Glass, 2010; Lee, 2010, 2012; Lee, McCaule, \& Jussim, 2013; Lee \& Kanazawa, 2015; Lee et al., 2015), and totems are also our teachers in a great sense today (Silverman, 1981). Our psychological totems are absolutely also our teachers. Yes, indeed, both Wilhelm Wundt (18321920) and Sigmund Freud (1956-1939) as our teachers and scientists, are definitely our psychological totems today!

\section{Endnotes}

1 The way to identify who does or does not actually believe their supernatural claims about Totems (e.g., aboriginal Australian kangaroos, or Michigan alum's wolverines) is contingent on the created and shared meaning of totems, certain things or objects among members of groups or tribes based on cultural meaning model (see Lee, Jussim \& McCauley, 1995, pp. 161-164). The symbolic and identity-based images or animals or interpretative abstract things or values/perceptions must have the meanings that are constructed, interpreted, and shared by and among certain group members also as demonstrated by various research perspectives in psychology (Bruner, 1990; Kelly, 1955; Maslow, 1971; Moscovici, 1988; Rogers, 1980; Tajfel, 1981), sociology (e.g., symbolic interactionist theory by Mead, 1934), and symbolic-interpretative anthropology (e.g., Geertz, 1973). For example, if group members do not believe in something-e.g., a totem or logo-image, they may not share the same meaning or identify with the totem or logo-image as others who believe it.

2 Ms. Rogene Kohler is a certified German translator who translated this paragraph from Wundt's original German writing into English.

3 With regard to the cross-cultural sample selection, the Chinese and American Psychology students were chosen for two reasons. First, due to the convenience of data collection, the authors had contact in China. Second, two samples could basically represent Eastern and Western educational systems and cultural values (Lee et al., 1999).

4 No significant difference was obtained with regard to other categories of cross-cultural participants (e.g., their education, age, gender or major). Also due to the nature and scope of the paper, we only briefly reported on the general findings relevant to totemic psychology to illustrate the importance of Wundt and Freud's work. Other details regarding the assessment procedures and results had to be omitted due to limited space but will be available upon request.

\section{References}

Alexander, H. B. (1916/2005). Native American mythology. Mineola, NY: Dover Publications, Inc.

Anderson, R. J. (1971). Attribution of quotations from Wundt. American Psychologist, 26(6), 590-593.

Arnett, J. (2008). The neglected 95\%: Why American psychology needs to become less American. American Psychologist, 63(7), 602-614.

Ausubel, D. P. (1956). Relationships between psychology and psychiatry: The hidden issues. American Psychologist, 11(2), 99-105.

Bartlett, F. C. (1920). Some experiments in the reproduction of folk-stories. Folklore, 31, 30-47.

Bartlett, F. C. (1932). Remembering: A study in experimental and social psychology. London: Cambridge University Press.

Bateson, G. (2002). Mind and nature: A necessary unity. Cresskill, NJ: Hampton Press, Inc.

Bauer, M. W., \& Gaskell, G. (2008). Social representations theory: A progressive research program for social psychology. Journal of the Theory of Social Behavior, 38(4), 335-353.

Blumenthal, A. L. (1975). A reappraisal of Wilhelm Wundt. American Psychologist, 30(11), 1081-1088.

Boas, F. (1916). The origin of totemism. American Anthropologist, 18(3), 319-326

Boring, E. G. (1957). A history of experimental psychology (2nd ed.). Englewood Cliffs, NJ: Prentice-Hall.

Brown, R. (2000). Social Identity Theory: Past achievements, current problems, and future challenges. European Journal of Social Psychology, 30, 745-778.

Bruner, J. (1956). Freud and the image of Man. American Psychologist, 11(9), 463-466.

Bruner, J. (1990). Acts of meaning. Cambridge, MA: Harvard University Press.

Cahan, E. D., \& White, S. H. (1992). Proposals for a second psychology. American Psychologist, 47(2), 224-235.

Curtis, S. E. (1972). In a sacred manner we live. New York: Weathervane Books.

Durkheim, E. (1902/1985). On totemism (trans. by R.A. Jones). History of Sociology, 5(2), 79-121.

Durkheim, E. (1915/2008). The elementary forms of the religious life. (trans. by J. W. Swain). Mineola, NY: Dover Publications, Inc.

Durkheim, E. (1974). Sociology and philosophy. (trans. by D. F. Pocock). New York: the Free Press.

Fancher, F. E. (2000). Snapshots of Freud in America, 1899-1999. American Psychologist, 55(9), 1025-1028.

Frazer, J. G. (1910). Totemism and exogamy. (4 vols), London: Macmillan 
Freud, S. (1913). The interpretation of dreams (trans. by A. A. Brill). New York: Macmillan.

Freud, S. (1913/1950). Totem and taboo (trans. By J. Strachey). New York: W.W. Norton \& Company.

Geertz, C. (1973), The interpretation of cultures. New York: Basic Books

Goldenweiser, A. A. (1910). Totemism: An analytical study. Journal of American Folk-Lore, 23, 179-293.

Goldenweiser, A. A. (1914). Elemente der Volkerpsychologie. Psychological Bulletin, 11(10), 387-391.

Goodwin, C. J. (2008). A history of modern psychology. New York: Wiley.

Haeberlin, H. K. (1916). The theoretical foundations of Wundt's folk-psychology. Psychological Review, 23(4), 279-302.

He, X. L. (2006). Totemism in Chinese minority ethnic groups (trans. by Z. G. Wang into English) Beijing, China: China Intercontinental Press.

He, X. L. (2007). Totems and Chinese culture. Nanjing, China: Jiangsu People's Press (in Chinese).

Hogg, M. A. (2006). Social identity theory. In P. J. Burke (Ed.), Contemporary social psychological theories (pp. 111-136). Palo Alto, CA: Stanford University Press.

Ichheiser, G. (1970). Appearance and reality: Misunderstanding in human relations. San Francisco, CA: Jossey-Bass.

Isaacson, R. (2000). A totem gesture. Geographical, 72(11), 6770 .

Jilet, W. G. (1982). Indian healing: Shamanic ceremonalialism in the Pacific Northwest today. Blaine, WA: Hancock House Publishers.

Jonaitis, A., \& Glass, A. (2010). The totem pole: An intercultural history. Seattle, Washington: University of Washington Press.

Jones, R. A. (2005). The secret of the totem. New York: Columbia University Press.

Jussim, L. (2012). Social perception and social reality: Why accuracy dominates bias and self-fulfilling prophecy. New York: Oxford University Press.

Jussim, L., \& Ashmore, R. (1997). Fundamental issues in the study of self and identity-contrast, contexts, and conflicts. In R. Ashmore \& L. Jussim (eds.), Selfand identity: Fundamental issues (pp. 218-230). New York: Oxford University Press.

Kelly, G. A. (1955). The psychology of personal constructs. New York: Norton.

King, D. C. (2008). First people: An illustrated history of American Indians. New York: DK Publishing.

Korn, J. H., Davis, R., \& Davis, S. F. (1991). Historians' and chairpersons' judgments of eminence among psychologists. American Psychologist, 46(7), 789-792.

Krippner, S. (2002). Conflicting perspectives on Shamans and Shamanism: Points and counterpoints. American Psychologist, 57, 962-977.

Lang, A. (1905). The secret of the totem. London: Macmillan.

Leahey, T. H. (2004). A history of psychology: Main currents in psychological thoughts (6th edition). Upper Saddle River, NJ: Prentice Hall.
Lee, Y-T. (1994). Why does psychology have cultural limitations? American Psychologist, 49, 524-525.

Lee, Y-T. (2010). What can We Learn from Wundt and Freud's Totemic Psychology? Paper presented in the 118th Annual Convention of American Psychological Association, August 12-15, San Diego, CA.

Lee, Y-T. (2012). Fields Notes of Native Peoples in Americas. Unpublished Manuscript. Univ of Toledo, Ohio.

Lee, Y-T. (2014). Categorical necessity and utility of stereotyping and totemic thinking: Analyzing and reviewing the stereotype EPA theory, social perception accuracy, and female hurricanes. Global Journal of Human-Social Science. 14 (2), 4351

Lee, Y-T., Beddow, M., Chan, S., \& Xu, C. (2015). Evolutionary and cross-cultural investigation of totemism, Daoism and other spiritual beliefs. Psychology of Religion and Spirituality, $7(4), 278-285$.

Lee, Y-T., \& Jussim, L. (2010). Back in the real world. American Psychologist, 65(2), 130-131.

Lee, Y-T., Jussim, L., \& McCauley, C. (1995). Stereotype accuracy: Toward appreciating group differences. Washington, DC: The American Psychological Association.

Lee, Y-T., Jussim, L., McCauley, C. (2013). Stereotypes as categories of knowledge: Complexity, validity, usefulness, and essence in perceptions of group differences. Advances in Psychological Sciences, 21(1), 1-21. DOI: 10.3724/SP.J.1042.2013.00001

Lee, Y-T, \& Kanazawa, S. K. (2015). An Introduction to the special issue on the nature and evolution of totemism, Shamanism, religions, and spirituality. Psychology of Religion and Spirituality, 7(4), 265-266.

Lee, Y-T., McCauley, C. R., \& Draguns, J. (Eds.). (1999). Personality and person perception across cultures. Mahwah, NJ: Lawrence Erlbaum Associates, Inc. Publishers.

Lee, Y-T., McCauley, C., \& Jussim, C. (2013). Stereotypes as valid categories of knowledge, and human perceptions of group differences. Social and Personality Psychology Compass, 7(7), 470486.

Lee, Y-T., McCauley, C., Moghaddam, F., \& Worchel, S. (2004). The Psychology of Ethnic and Cultural Conflict. Westport, CT: Praeger Publishers.

Lee, Y-T., \& Tiamiyu, M. (2010). What is in a name? Identity Perceptions between Individualistic and Collectivistic Cultures. Paper presented the annual convention of the Association for Psychological Science, May 29-31, Boston, Massachusetts.

Levi-Strauss, C. (1962). Totemism. (trans. by R. Needham). Boston, MA: Beacon Press.

Levi-Strauss, C. (1966). The savage mind. Chicago, IL: University of Chicago Press.

Lin, H. (2001). The history of Chinese Shamanism (Wu Nuo Shi). Guangzhou: Huacheng Publishers (in Chinese).

Long, J. (1791/1922). John Long's voyages and travels in the years 1768-1788. Chicago, IL: The Lakeside Press.

Lukes, S. (1972). Émile Durkheim: His life and work-a historical and critical study. New York: Harper \& Row, Publishers 
Malinowski, B. (1926). Myth in primitive psychology. London: Norton.

Malinowski, B. (1927). Sex and Repression in Savage Society. London: Kegan Paul, Trench, Trubner \& Co.

Maslow, A. (1971). The farther reaches of human nature. New York: Viking.

McLennan, J. F. (1869). The worship of animals and plants. Fortnightly Review, 6, 407-427 and 562-582.

McLennan, J. F. (1870). The worship of animals and plants. Fortnightly Review, 7, 194-216.

Mead, G. H. (1934). Mind, self, and society. Chicago: University of Chicago Press.

Meng, H. Y. (2005). Search for the mysterious Shamnic world. Beijing: Xiyuan Publishers (in Chinese).

Monroe, M. H. (n.d.). Aboriginal totemism. Retrieved from http://austhrutime.com/aboriginal_totemism.htm

Morgan, L. H. (1877/1974). Ancient society or research in the lines of human progress from savage through barbarism to civilization (with introduction \& annotation by E. B. Leacock). Gloucester, MA: The World Publishing Co.

Moscovici, S. (1973). Foreword. In C. Herzlich, Health and illness: A social psychological analysis. London: Academic Press, pp. v-xiv.

Moscovici, S. (1984). The phenomenon of social representations. In R. Farr \& S. Moscovici (eds.), Social representations. New York: Cambridge University Press.

Moscovici, S. (1988). Notes towards a description of social representations. European Journal of Social Psychology, 18 (3), 211-250.

Moscovici, S. (2000). Social representations: Explorations in social psychology (G. Duveen Ed.). New York, NY: Wiley.

Palmer, C. T., Steadman, L. B., Cassidy, C., \& Coe, K. (2008). Totemism, metaphor and tradition: Incorporating cultural traditions into evolutionary psychology explanations of religion. Zygon: Journal of Religion and Science, 43(3), 919-935.

Pedersen, M. (2001). Totemism, animism, and North Asian indigenous ontologies. Journal of Royal Anthropological Institute (N.S.), 7, 411-427.

Pickren, W. E., \& Rutherford, A. (2010). A history of modern psychology in context. Hoboken, NJ: Wiley.

Rivers, W. H. R. (1909). Totemism in Polynesia and Melanesia. The Journal of the Royal Anthropological Institute of Great Britain and the Ireland, 39, 156-180.

Rogers, C. R. (1980). A way of being. Boston: Houghton Mifflin.

Silverman, S. S. (1981) (ed.) Totems and teachers: Perspectives in the history of anthropology. New York: Columbia University Press.
Spencer, H. (1870). The origin of animal worship, etc. The Fortnightly Review, 7(7), 535-550.

Sue, D. W., \& Sue, D. (2012). Counseling the culturally diverse: Theory and practice. Hoboken, NJ: Wiley.

Swann, W. B., Jetten, J., Gómez, A., Whitehouse, H., \& Bastian, B. (2012). When group membership gets personal: A theory of identity fusion. Psychological Review, 119(3), 441456.

Tajfel, H. (1981). Human groups and social categories. Cambridge: Cambridge University Press.

Tajfel, H., \& Turner, J.C. (1986). The social identity theory of intergroup behavior. In S. Worchel \& W.G. Austin (Eds.), The psychology of intergroup relations (pp. 7-24). Chicago: Nelson-Hall.

Tolman, A., \& Reedy, R. (1998). Implementation of a culturespecific intervention for a native American community. Journal of Clinical Psychology in Medical Settings, 5(3), 381392.

Triandis, H. C. (2009). Fooling ourselves: Self-perception in politics, religion, and terrorism. Westport, CT: Praeger

Vitebsky, P. (1995). The Shaman: Voyages of the soul trance, ecstansy and healing from Siberia to the Amazon. London: Duncan Baird Publishers.

Wagner, W., \& Hayes, N. (2005). Everyday Discourse and Common-Sense: The Theory of Social Representation. New York: Palgrave Macmillan.

Wang, D. Y., \& Song, B. Z. (2007). Mystery of the Indians: Revised edition of American Indian Totems. Beijing, Chinese Times Press (in Chinese).

Winkelman, M. (2004). Shamanism as the original neurotheology. Zygon, 39 (1), 193-217.

Wundt, W. (1897). Ethics: Facts and laws of the moral life (trans. by G. Gulliver \& E. B. Titchener). New York: The Macmillan Co.

Wundt, W. (1902). Grundzüge der physiologischen Psychologie. Leipzig: Verlag von Wilhelm Engelmann.

Wundt, W. (1905). Völkerpsychologie: Eine Untersuchung der Entwicklungsgesetze von Sprache, Mythus und Sitte (Zweiter Band Mythus und Religion, Erster Teil). Leipzig: Verlag von Wilhelm Engelmann.

Wundt, W. (1912). Elemente der Völkerpsychologie. Leipzig: Alfred Kröner Verlag.

Wundt, W. (1916). Elements of folk psychology: Outlines of a psychological history of the development of mankind (trans. E. L. Schaub). New York: The Macmillan Co.

Wurtz, K. R. (1961). A survey of important psychological books. American Psychologist, 16(4), 192-194. 